\title{
Reiki and related therapies in the dialysis ward: an evidence-based and ethical discussion to debate if these complementary and alternative medicines are welcomed or banned
}

Martina Ferraresi ${ }^{1 *}$, Roberta Clari ${ }^{1}$, Irene Moro ${ }^{1}$, Elena Banino ${ }^{2}$, Enrico Boero ${ }^{2}$, Alessandro Crosio ${ }^{2}$, Romina Dayne ${ }^{2}$, Lorenzo Rosset ${ }^{2}$, Andrea Scarpa $^{2}$, Enrica Serra ${ }^{2}$, Alessandra Surace ${ }^{2}$, Alessio Testore ${ }^{2}$, Nicoletta Colombi ${ }^{3}$ and Giorgina Barbara Piccoli ${ }^{*}$

\begin{abstract}
Background: Complementary and Alternative Medicines (CAMs) are increasingly practiced in the general population; it is estimated that over $30 \%$ of patients with chronic diseases use CAMs on a regular basis. CAMs are also used in hospital settings, suggesting a growing interest in individualized therapies. One potential field of interest is pain, frequently reported by dialysis patients, and seldom sufficiently relieved by mainstream therapies. Gentle-touch therapies and Reiki (an energy based touch therapy) are widely used in the western population as pain relievers.

By integrating evidence based approaches and providing ethical discussion, this debate discusses the pros and cons of CAMs in the dialysis ward, and whether such approaches should be welcomed or banned.
\end{abstract}

Discussion: In spite of the wide use of CAMs in the general population, few studies deal with the pros and cons of an integration of mainstream medicine and CAMs in dialysis patients; one paper only regarded the use of Reiki and related practices. Widening the search to chronic pain, Reiki and related practices, 419 articles were found on Medline and 6 were selected (1 Cochrane review and 5 RCTs updating the Cochrane review). According to the EBM approach, Reiki allows a statistically significant but very low-grade pain reduction without specific side effects. Gentle-touch therapy and Reiki are thus good examples of approaches in which controversial efficacy has to be balanced against no known side effect, frequent free availability (volunteer non-profit associations) and easy integration with any other pharmacological or non pharmacological therapy. While a classical evidence-based approach, showing low-grade efficacy, is likely to lead to a negative attitude towards the use of Reiki in the dialysis ward, the ethical discussion, analyzing beneficium (efficacy) together with non maleficium (side effects), justice (cost, availability and integration with mainstream therapies) and autonomy (patients' choice) is likely to lead to a permissive-positive attitude.

Summary: This paper debates the current evidence on Reiki and related techniques as pain-relievers in an ethical framework, and suggests that physicians may wish to consider efficacy but also side effects, contextualization (availability and costs) and patient's requests, according also to the suggestions of the Society for Integrative Oncology (tolerate, control efficacy and side effects).

Keywords: Chronic pain, Chronic kidney disease, Alternative, Allied and complementary medicine, Reiki, Touch therapy

\footnotetext{
*Correspondence: marti.ferraresi@gmail.com; gbpiccoli@yahoo.it

'SS Nephrology ASOU, san Luigi (regione Gonzole 10), Orbassano 10043, Torino, Italy

Full list of author information is available at the end of the article
} 


\section{Background}

Complementary or allied-alternative medicines (CAMs) are increasingly being used, in particular in patients affected by chronic diseases or diseases "without therapy" [1-3]. The world prevalence of CAMs varies considerably (35-75\% in non-selected general populations); in this context, the reluctance to admit CAM use may underestimate it [4-15]. On the other hand, the inclusion of prayer, which is usually considered as a part of the CAMs, can double their prevalence; this is an interesting and highly discussed issue, as not all Authors agree to consider religious beliefs as a part of a therapeutic pathway. However, for the sake of the present review, we would like to mention that one of the first randomized controlled trials on CAMs published on a core clinical journal, the MANTRA trial, regarded the healing effect of prayer [12].

A few reports have dealt with the use of CAMs in Nephrology and Dialysis, underlining their growing diffusion and the need for specific education in renal medicine $[16,17]$.

The opening of the "conventional" to the "complementary" raises new problems: the rapid increase in demand for CAMs requires an adequate medical education and a change in the attitude of hospitals and physicians towards CAMs. According to a 2001 survey, CAMs were taught in about $40 \%$ of European medical schools and in $64 \%$ of USA ones [18-20]. While several problems remain to be solved (primarily the lack of certification and controls), the position statements of some leading medical societies highlight the responsibility of medical doctors to counsel and guide patients along this complex pathway [21]. Resolution No. 400, May 1997 of the European Parliament and Resolution No. 1206, November 1999 of the Council of Europe stress the need to guarantee citizens the greatest freedom of choice of treatment, ensuring the highest level of security and the most accurate information on the safety, quality and effectiveness of non-conventional treatments, inviting member states to provide information on CAMs [22].

The National Institutes of Health of the USA has a dedicated centre and a site (National Center for Complementary and Alternative Medicine, NCCAM). CAMs are also acquiring space in the Cochrane Collaboration and some important series, such as the BMC, have dedicated a journal to CAMs dealing with studies supported by the National Institutes of Health [23-25]. The Qualitative Methods Working Group of NIH developed a methodological manifesto in 1997 to identify study designs and analyses applicable to CAMs, pursuing standardization or suggesting new approaches, such as the "Whole System Approach", aimed at respecting the personalization of therapies, which is often basic to the practice of CAMs [24-33]. Within these limits, the application of evidencebased medicine (EBM) to the analysis of CAMs confirms the versatility of EBM as a problem-solving approach, disentangling the complex relationship between "Medicine and Medicines" [34-37].

The discussion of the case of Reiki may highlights the controversial points in the discussion on the attitude towards CAMs in the dialysis ward, and the problemsolving approach integrating EBM with a formal ethical outline, developed in the context of the EBM course of the san Luigi Medical School, may represent an example applicable on other CAMs in similar settings [38-42].

\section{Discussion}

The interest for Reiki and related CAMs is high in the western population, but the "usual" sources of information are limited and often of low quality

The increasing interest in "non-conventional" approaches is a leading theme in our society [1-3,43-46]. In this context, the so-called "mind and body therapies", healing touch or Reiki, may represent a prototype of non-medical approaches in a highly "medicalized" population such as dialysis patients.

Reiki (霊気) is a Japanese word meaning "universal life energy"; it is a healing practice consisting in the light laying of hands on or just above the person, with the theoretical goal of facilitating the person's healing response by getting in touch with the universal energy, which is thought to support the body's innate capacity for self-healing [47]. Reiki can also be practiced as selftreatment (self-help) [48-51].

Reiki was described in detail by the Japanese master Dr. Mikao Usui in the early 1900s through his study of ancient Tibetan healing arts and the laying on of hands healing tradition. It was brought to the mainland United States via Hawaii during the 1940s, and was introduced into Europe in the 1980s. Treatment consists in at least four sessions of 30-90 minutes, in which the practitioner places his/her hands lightly on or just above the client's body, palms down, using different hand positions [47].

The popularity of Reiki is increasing in several countries, probably because the healing approach is non-traumatic and easily integrated with conventional therapies [52,53]. In spite of its diffusion, the baseline mechanism of action has not been demonstrated, as the few attempts to investigate it have led to inconsistent results [54].

For the sake of the present analysis, the evidence was retrieved by two pathways, mimicking the patient's and the physician's side.

The first search (patient's perspective) was performed as a tool to define "what the patient knows" as basis for an evidence-based, informed discussion. A non-systematic search on Google and Yahoo, increasingly used both as a tool to better understand patients' requests and as a clinical problem-solving strategy, confirms the interest in the subject. The large number of citations retrieved with 
the single term "Reiki" on the most common search engines, plus over 1000 relevant titles on Medline, provided preliminary contextualization and support of the patient's request. However, the high number of commercial sites on Google and Yahoo should be a warning about the economic pressure (Table 1) [55-61].

The classic EBM approach, based upon treatment efficacy, underlines the limited evidence on Reiki and related

\section{CAMs and the low-grade effect on pain}

This conclusion stems from a second search (physician's perspective), that was performed on Pubmed and CINAHL, according with the classic rules of EBM database searches.

Dialysis is a very specific niche for complex heterogeneous patients, often with high comorbidity; it is rare to find efficacy studies on CAMs tailored to this population. In fact, during a first, preliminary search analysis combining the free terms "Reiki", "Dialysis" and "Pain", very few papers were retrieved ( 8 papers matching "Reiki" and "Dialysis", 3 also with "Pain"), but only one paper dealt with such a case, leading us to broaden the search strategy to "Reiki and pain" [62].

Therefore, a second broader search was built on Pubmed and CINAHL, combining the following terms: (Dialysis OR Amyloidosis OR Myeloma OR Pain OR Fatigue) AND (Reiki OR (Healing touch) OR (Touch therapy) OR (Therapeutic touch) OR (Laying on of hands)). The search, limited to the last 5 years, on the account of the date of last updating of the Cochrane Review and to article in English, retrieved both a relevant Cochrane review and a series of 5 recent RCTs on Reiki and chronic pain (Table 2, Figure 1) [63-67]. The studies are highly heterogeneous, both in the Cochrane review (24 studies) and in the subsequent years (5 RCTs). Pain was assessed by various methods, with a visual analogue scale being the one most commonly used; control groups were different and the reasons for pain encompassed different diseases. Within these limits, the main results support a significant reduction of pain in patients undergoing touch therapies in general and Reiki in particular (Table 2). The overall quality of the review and of the selected RCTs was high (Table 2), in line with recent reports of a comparable quality of studies on CAMs and "mainstream Medicine" at least in the English language [34].

Nevertheless, statistical significance is not synonymous with clinical relevance: in the Cochrane review, the mean reduction of pain was less than one unit on a $0-$ 10 scale, a limit probably not perceived by human beings, and in the 5 RCTs published after the review, Reiki was effective on pain in 2 studies and had no significant benefit in 3. Pain reduction was measured with a VAS scale in both articles and can be approximated to $1.5 \mathrm{~cm}$ (Table 2).

No study reported adverse events linked to the procedure.

Side effects were not specifically reported in the Cochrane review. Only one out of the 5 RCTs published after the Cochrane review reported specifically on side

Table 1 Evidence retrieved on web search engines: quantitative analysis of the first $\mathbf{2}$ pages of Google and Yahoo

\begin{tabular}{|c|c|c|c|c|c|}
\hline Search terms & Search engine & Items & $\begin{array}{c}\text { Commercial/ } \\
\text { non-commercialsites } \\
\text { in the first } 2 \text { pages }\end{array}$ & $\begin{array}{l}\text { Sites providing references } \\
\text { (non-commercial links in } \\
\text { the first } 2 \text { pages) }\end{array}$ & $\begin{array}{l}\text { No. sites in } \\
\text { common in Google } \\
\text { and Yahoo }\end{array}$ \\
\hline \multirow[t]{2}{*}{ Reiki } & Google & 58500000 & $6 / 14$ & 3 & 6 \\
\hline & Yahoo & 44900000 & $6 / 14$ & 6 & \\
\hline \multirow[t]{2}{*}{ Reiki medicine } & Google & 17800000 & $17 / 3$ & 2 & 1 \\
\hline & Yahoo & 5690000 & $19 / 1$ & 1 & \\
\hline \multirow[t]{2}{*}{ Reiki Torino } & Google & 3680000 & $18 / 2$ & 0 & 0 \\
\hline & Yahoo & 51100 & $10 / 10$ & 0 & \\
\hline \multirow[t]{2}{*}{ Reiki use } & Google & 3060000 & $18 / 2$ & 2 & 0 \\
\hline & Yahoo & 55300 & $20 / 0$ & 0 & \\
\hline \multirow[t]{2}{*}{ Reiki pain } & Google & 10700000 & $1 / 19$ & 9 & 4 \\
\hline & Yahoo & 7150000 & $2 / 18$ & 4 & \\
\hline \multirow[t]{2}{*}{ Reiki dialysis } & Google & 590000 & $4 / 16$ & 0 & 7 \\
\hline & Yahoo & 193000 & $6 / 14$ & 0 & \\
\hline \multirow[t]{2}{*}{ Reiki cost effectiveness } & Google & 333000 & $12 / 8$ & 12 & 5 \\
\hline & Yahoo & 112000 & $15 / 5$ & 9 & \\
\hline \multirow[t]{2}{*}{ Reiki contra- indications } & Google & 120000 & $9 / 11$ & 2 & 9 \\
\hline & Yahoo & 30900 & $6 / 14$ & 1 & \\
\hline
\end{tabular}


Table 2 Characteristics of selected articles

\begin{tabular}{|c|c|c|c|c|c|c|c|c|c|}
\hline $\begin{array}{l}\text { Author, } \\
\text { year }\end{array}$ & Study design & Participants & Measurements & Treatment & Comparison & Outcomes & Results & Side effects & $\begin{array}{l}\text { CASP } \\
\text { score }\end{array}$ \\
\hline So, 2008 & Review & $\begin{array}{l}24 \text { studies } \\
\text { (1153 participants) }\end{array}$ & $\begin{array}{l}\text { VAS, NRS, } \\
\text { McGill Pain Index, } \\
\text { SF-36, analgesic } \\
\text { usage, MPAC, FACT }\end{array}$ & $\begin{array}{l}\text { Touch } \\
\text { therapies(TT): } \\
\text { Reiki, Healing } \\
\text { Touch, } \\
\text { Therapeutic Touch }\end{array}$ & $\begin{array}{l}\text { Sham placebo } \\
\text { or 'no treatment' } \\
\text { control }\end{array}$ & $\begin{array}{l}\text { Pain (acute } \\
\text { or chronic) }\end{array}$ & $\begin{array}{l}\text { Statistically significant } \\
\text { reduction of pain with } \\
\text { different treatment, } \\
\text { especially with Reiki } \\
\text { ( } 95 \% \text { Cl: }-1.16 \text { to }-0.50 \text { ) }\end{array}$ & Not evaluated & $7 / 10$ \\
\hline $\begin{array}{l}\text { McCormack, } \\
2009\end{array}$ & RCT & $\begin{array}{l}\mathrm{n}=90 \text { elderly patients with } \\
\text { post-surgical pain: } \mathrm{n}=30 \\
\text { non-contact therapeutic } \\
\text { touch, } \mathrm{n}=30 \text { metronome } \\
\text { treatment, } \mathrm{n}=30 \text { no } \\
\text { treatment }\end{array}$ & $\begin{array}{l}\text { VAS, MPAC,TAS, } \\
\text { HAT,pupil size }\end{array}$ & Reiki & $\begin{array}{l}\text { Routine care, } \\
\text { placebo }\end{array}$ & $\begin{array}{l}\text { Post-operative } \\
\text { pain }\end{array}$ & $\begin{array}{l}\text { Statistically significant } \\
\text { reduction of pain in the } \\
\text { Reiki group, worsening } \\
\text { of pain in the metronome } \\
\text { group ( } p<0.01)\end{array}$ & Not reported & $7.5 / 10$ \\
\hline $\begin{array}{l}\text { Maclntyre, } \\
2008\end{array}$ & $\begin{array}{l}\text { RCT, not } \\
\text { blinded }\end{array}$ & $\begin{array}{l}\mathrm{n}=290 \text { patients } \\
\text { (mean age } 64 \text { ) } \\
\text { undergoing first time } \\
\text { elective coronary } \\
\text { artery bypass surgery } \\
\mathrm{n}=237 \text { at the end of } \\
\text { the study }\end{array}$ & MEDD, STAI & Healing Touch & $\begin{array}{l}\text { Visitors } \\
\text { and no } \\
\text { intervention }\end{array}$ & $\begin{array}{l}\text { Post-operative } \\
\text { pain, anxiety, } \\
\text { physical and } \\
\text { mental status, } \\
\text { length of stay }\end{array}$ & $\begin{array}{l}\text { Significant reduction of } \\
\text { hospital stay and anxiety. } \\
\text { No significant reduction } \\
\text { of pain }\end{array}$ & Not reported & $7.5 / 10$ \\
\hline $\begin{array}{l}\text { Frank, } \\
2007\end{array}$ & $\begin{array}{l}\text { RCT, patients, } \\
\text { data collection } \\
\text { staff and data } \\
\text { analyst blinded }\end{array}$ & $\begin{array}{l}\mathrm{n}=82 \text { females } \\
\text { undergoing } \\
\text { Stereotactic Core } \\
\text { Breast Biopsy: } \\
\mathrm{n}=42 \text { intervention, } \\
\mathrm{n}=40 \text { placebo }\end{array}$ & VAS & $\begin{array}{l}\text { Therapeutic } \\
\text { Touch (TT) }\end{array}$ & Sham Reiki & $\begin{array}{l}\text { Post-biopsy pain, } \\
\text { lidocaine/ } \\
\text { epinephrine dosage }\end{array}$ & $\begin{array}{l}\text { Increase of pain in both } \\
\text { groups, not statistically } \\
\text { significant }\end{array}$ & $\begin{array}{l}\text { Increase of pain } \\
\text { in both groups }\end{array}$ & $7.5 / 10$ \\
\hline $\begin{array}{l}\text { Assefi, } \\
2008\end{array}$ & $\begin{array}{l}\text { RCT, patients, } \\
\text { data collection } \\
\text { staff and data } \\
\text { analyst blinded }\end{array}$ & $\begin{array}{l}\mathrm{n}=100 \text { adults with } \\
\text { fibromyalgia } \\
\text { ( } 23 \text { real direct } \\
\text { Reiki: } 24=\text { real distant } \\
\text { Reiki, } 23=\text { sham direct } \\
\text { Reiki, } 23=\text { sham } \\
\text { distant Reiki) }\end{array}$ & VAS & Reiki & Sham Reiki & $\begin{array}{l}\text { Pain, fatigue, sleep } \\
\text { quality, well-being }\end{array}$ & $\begin{array}{l}\text { Neither Reiki nor touch } \\
\text { improve the symptoms } \\
\text { of fibromyalgia in all groups }\end{array}$ & Not reported & $7.5 / 10$ \\
\hline $\begin{array}{l}\text { Aghabati } \\
2010\end{array}$ & RCT & $\begin{array}{l}\mathrm{n}=90 \text { patients with } \\
\text { cancer and normal } \\
\text { level of consciousness, } \\
\text { age } 15-65: \mathrm{n}=30 \mathrm{TT} \\
\mathrm{n}=30 \text { placebo, } \\
\mathrm{n}=30 \text { control }\end{array}$ & VAS, RFS & $\begin{array}{l}\text { Therapeutic } \\
\text { Touch (TT) }\end{array}$ & $\begin{array}{l}\text { Mimic } \\
\text { therapeutic } \\
\text { touch and no } \\
\text { intervention }\end{array}$ & Pain, fatigue & $\begin{array}{l}\text { Statistically significant } \\
\text { decrease in pain and } \\
\text { fatigue in TT vs placebo } \\
\text { or control ( } p=0.04)\end{array}$ & $\begin{array}{l}\text { Excess energy and } \\
\text { anxiety in both } \\
\text { groups }\end{array}$ & $8 / 10$ \\
\hline
\end{tabular}




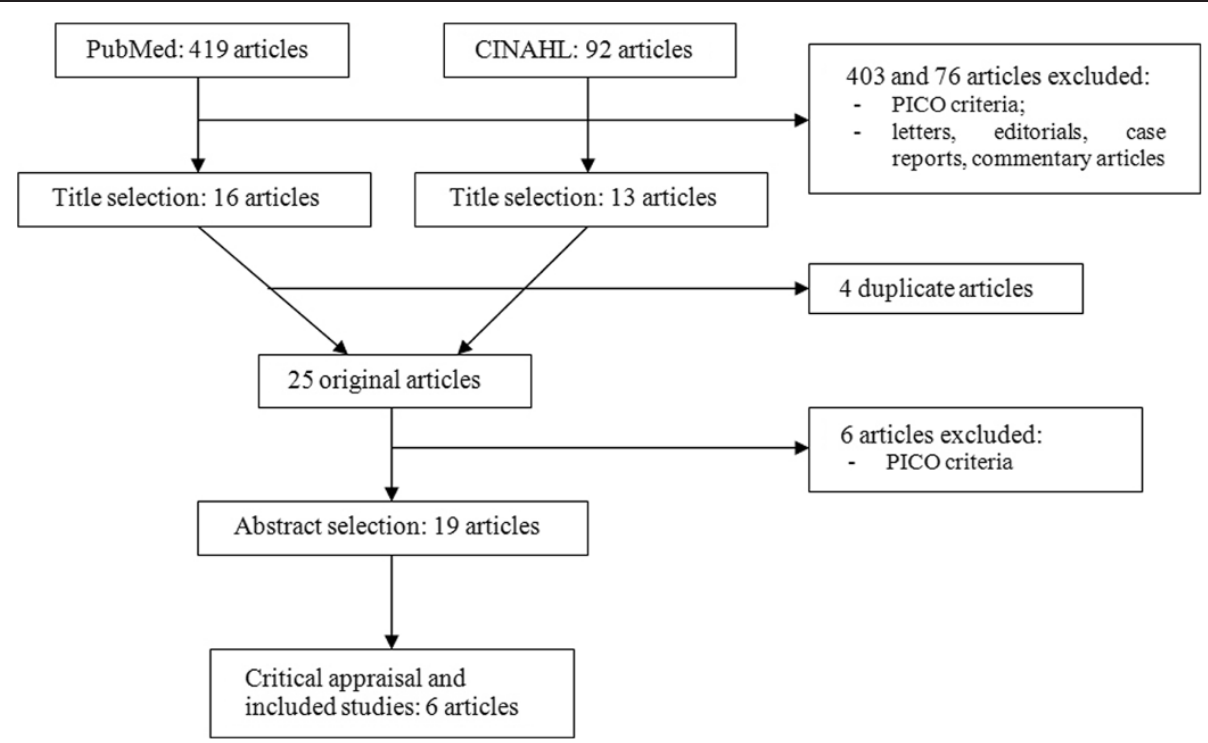

Figure 1 Flow chart of the papers retrieved. Legend: PICO: Patient/Population, Intervention, Comparison, Outcome, a method of putting together the better search strategy; CINAHL: Cumulative Index to Nursing and Allied Health Literature, a data bank.

effects; they were described both in the Reiki and Sham Reiki groups. The main side effects were "excess energy" or anxiety (41\%); $18 \%$ reported worsening of sleep or depression. The side effects were no different with Reiki or placebo [66]. One other study showed an increase of pain in groups of patients undergoing Stereotactic Core Breast Biopsy treated with Touch Therapies and with Sham Reiki [65]. This increase in pain-anxiety was presumably linked to the fact of "being studied", suggesting that even the placebo effect may be two-faceted and that physicians should also control for the negative interferences of "sham" treatments.

The EBM approach may not be sufficient to answer whether or not to facilitate Reiki in the dialysis ward without the application of an ethical framework

The overall picture deriving from the first steps of our analysis is thus of a widely used treatment of significant but limited efficacy, devoid of side effects, in no case inferior to placebo or the controls (Table 2).

While decisions on vital treatments, such as antibiotics or anti-neoplastic drugs, are mainly based on efficacy, decisions on chronic therapies, such as antihypertensives or on support therapies take into great account the expected side effects, leading some experts to conclude that the least effective treatment may occasionally be the best choice [16,68-70].

The shift from efficacy to tolerance has important philosophical implications.

The analysis according to the four main principles of principlist ethics may be a useful pragmatic guide for analysis [38-42]. The principles may be defined and contextualized as follows: beneficence - actions intended to benefit the patient; this was considered equivalent to therapeutic efficacy. Non-maleficence- actions intended not to harm or bring harm to the patient; this was considered equivalent to side effects. Justice - defined as being fair or just to the wider community in terms of the consequences of an action; this was considered to include the costs of therapy and the eventual integration with other treatments. Autonomy - respect for individuals and their ability to make decisions with regard to their own health and future; this was considered a reason to favour all non-maleficent therapies when chosen by the patient. The principle of beneficence supports a limited positive effect of Reiki, hardly perceivable in terms of pain decrease, thus questioning the opportunity of the integration of this therapy in the dialysis ward. However, the lack of relevant side effects (non-maleficence), the potential integration with other therapies and the negligible costs, at least in settings where Reiki is offered by non-profit volunteer associations (justice), together with the desire of the patient to "do something" for his pain (autonomy), on the contrary clearly support the choice of integrating Reiki into the patient's therapies.

These considerations are in line with the suggestions of the Society for Integrative Oncology in the case of treatments with limited efficacy but without relevant side effects: "tolerate, encourage caution, closely monitor effectiveness" [71].

\section{Conclusions}

The growing diffusion of CAMs in chronic diseases will increasingly confront the Nephrologist with the problem 
of integrating CAMs into Renal Replacement Therapies; this topic is a novelty for most Nephrologists and there is a need to acquire problem-solving tools.EBM offers an analytical pathway that is very interesting in the case of new diseases or non-codified therapies and is particularly suitable to the study of CAMs. The integration of an ethics-based discussion may offer interesting tools to systematically face such issues.

In the case of Reiki, the results of a systematic review, supplemented by a further updating, demonstrate a statistically significant but clinically barely relevant benefit. The use of Reiki should therefore be probably discouraged if only efficacy is considered, but chosen if the emphasis is on "non-maleficium" or the patient's autonomy; the issue of justice modulates the choice according to the burden of overall costs, and the availability of the treatment in the different settings.

The additional need of an ethical discussion based on sound evidence-based results to tackle new problems in our "old" context is in line with the approaches suggested in a different field by the Society for Integrative Oncology in the case of treatments with limited efficacy but without relevant side effects: "tolerate, encourage caution, closely monitor effectiveness" [71].

\section{Summary}

The present debate, integrating evidence based approaches and ethical framework, tries to balance the pros and cons of the systematic introduction of such approaches in the dialysis ward. In spite of the wide use of CAMs in the general population, few studies deal with the pros and cons of an integration of mainstream medicine and CAMs in dialysis patients; one paper only regarded the use of Reiki and related techniques. According to the EBM approach, Reiki allows a statistically significant but very low-grade pain reduction without specific side effects. However, the ethical discussion leads to a permissive-positive attitude.

This paper suggests that physicians may wish to consider efficacy but also side effects, contextualization (availability and costs) and patient's requests, according also to the suggestions of the Society for Integrative Oncology (tolerate, control efficacy and side effects).

\section{Competing interests}

The authors declare that they have no competing interest.

\section{Authors' contributions}

GBP and MF conceived and wrote the manuscript. NC provided the historical references and perspective. RC, IM, EB, EB, AC, RD, LR, ES, AS AT, working in group in the EBM course of the san Luigi Medical School of Torino, Italy, performed the Internet searches, retrieved the evidence, draw the tables, drafted different parts of the manuscript, and reviewed the text. All authors read and approved the final manuscript.

\section{Acknowledgements}

The authors would like to greatly thank the staff of the medical Library of the san Luigi Medical School for their continuous support and dr. Peter Christie for his careful language editing.

\section{Author details}

${ }^{1}$ SS Nephrology ASOU, san Luigi (regione Gonzole 10), Orbassano 10043, Torino, Italy. ${ }^{2}$ Medical School, Università degli Studi di Torino, san Luigi, (regione Gonzole 10), Orbassano 10043, Torino, Italy. ${ }^{3}$ Biomedical Library Università degli Studi di Torino, san Luigi, (regione Gonzole 10), Orbassano 10043, Torino, Italy.

Received: 4 October 2012 Accepted: 3 June 2013

Published: 21 June 2013

\section{References}

1. Eisenberg DM, Kessler RC, Foster C, Norlock FE, Calkins DR, Delbanco TL: Unconventional medicine in the United States, Prevalence, costs, and patterns of use. N Engl J Med 1993, 328(4):246-52.

2. Staud R: Effectiveness of CAM therapy: understanding the evidence. Rheum Dis Clin North Am 2011, 37(1):9-17.

3. NCCAM: What is complementary and alternative medicine. Available at: http:/nccam.nih.gov/health/whatiscam. Accessed April 24, 2012.

4. Eisenberg DM, Davis RB, Ettner $\mathrm{SL}$, et al: Trends in alternative medicine use in the United States, 1990-1997: results of a follow-up national survey. JAMA 1998, 280(18):1569-75.

5. Ernst E: Obstacles to research in complementary and alternative medicine. Med J Aust 2003, 179(6):279-80.

6. Barnes PM, Powell-Griner E, McFann K, Nahin RL: Complementary and alternative medicine use among adults: United States, 2002. Adv Data 2004, 343:1-19.

7. Jantos $\mathrm{M}$, Kiat $\mathrm{H}$ : Prayer as medicine: how much have we learned? Med J Aust 2007, 186(10 Suppl):S51-3.

8. McCaffrey AM, Eisenberg DM, Legedza AT, Davis RB, Phillips RS: Prayer for health concerns: results of a national survey on prevalence and patterns of use. Arch Intern Med 2004, 164(8):858-62.

9. O'Connor PJ, Pronk NP, Tan A, Whitebird RR: Characteristics of adults who use prayer as an alternative therapy. Am J Health Promot 2005, 19(5):369-75.

10. Millennium Cohort Study Team, White MR, Jacobson IG, Smith B, Wells TS, Gackstetter GD, Boyko EJ, Smith TC: Health care utilization among complementary and alternative medicine users in a large military cohort. BMC Complement Altern Med 2011, 11:27.

11. Thomas KJ, Nicholl JP, Coleman P: Use and expenditure on complementary medicine in England: a population based survey. Complement Ther Med 2001, 9(1):2-11.

12. Krucoff MW, Crater SW, Gallup D, Blankenship JC, Cuffe M, Guarneri M, Krieger RA, Kshettry VR, Morris K, Oz M, Pichard A, Sketch MH Jr, Koenig HG, Mark D, Lee KL: Music, imagery, touch, and prayer as adjuncts to interventional cardiac care: the Monitoring and Actualisation of Noetic Trainings (MANTRA) II randomized study. Lancet 2005, 366(9481):211-7.

13. Ernst E, Cassileth BR: The prevalence of complementary/alternative medicine in cancer: a systematic review. Cancer 1998, 83(4):777-82

14. Patterson RE, Neuhouser ML, Hedderson MM, Schwartz SM, Standish L, Bowen DJ, Marshall LM: Types of alternative medicine used by patients with breast, colon, or prostate cancer: predictors, motives, and costs. J Altern Complement Med 2002, 8(4):477-85.

15. Richardson MA, Sanders T, Palmer JL, Greisinger A, Singletary SE: Complementary/alternative medicine use in a comprehensive cancer center and the implications for oncology. J Clin Oncol 2000, 18(13):2505-14.

16. Burrowes JD, Van Houten G: Use of alternative medicine by patients with stage 5 chronic kidney disease. Adv Chronic Kidney Dis 2005, 12(3):312-25.

17. Nowack R, Birck R: Complementary and alternative medicine is popular among chronic renal failure patients-renal teams must increase their competence to advise patients with respect to efficacy and safety. Evid Based Nurs 2012, 15(1):29-30.

18. Aratani L: Mainstream Physicians Try Such Alternatives as Herbs, Acupuncture and Yoga. Washington Post; 2009. 2009-06-09.

19. Press Release: Latest Survey Shows More Hospitals Offering Complementary and Alternative Medicine Services. American Hospital Association. 2008-09-15 - 
Available at: http://www.aha.org/presscenter/pressrel/2008/080915-pr-cam. shtml - Accessed April 24, 2012.

20. Expert Committee on Complementary Medicines in the Health System: Complementary Medicines in the Australian Health System. Report to the Parliamentary Secretary to the Minister for Health and Ageing. Canberra: Commonwealth of Australia; 2003. Available at: http://www.tga.gov.au/pdf/ archive/committees-eccmhs-report-031031.pdf Accessed April 24, 2012.

21. Steyer TE: Complementary and alternative medicine: a primer. Fam Pract Manag 2001, 8(3):37-42.

22. A European approach to non-conventional medicine: Official Journal L 144 , 04/06/1997 P. 0019-0027 Resolution 1206 (1999) Extract from the Official Gazette of the Council of Europe - (November 1999).

23. The BMC-series journals; 2012. Available at: http://www.biomedcentral.com/ authors/bmcseries. Accessed April 24, 2012.

24. The National Institutes of Health: The National Institutes of Health. Available at: http://www.nih.gov/. Accessed April 24, 2012.

25. Ezzo J, Berman BM, Vickers AJ, Linde K: Complementary medicine and the Cochrane Collaboration. JAMA 1998, 11(280):1628-30.

26. Margolin A, Avants SK, Kleber HD: Investigating alternative medicine therapies in randomized controlled trials. JAMA 1998, 11(280):1626-8.

27. Hansen $\mathrm{K}$, Kappel KJ: The proper role of evidence in complementary/ alternative medicine. Med Philos 2010, 35:7-18.

28. Mason S, Tovey P, Long AF: Evaluating complementary medicine: methodological challenges of randomized controlled trials. BMJ 2002, 325(7368):832-4

29. Levin JS, Glass TA, Kushi LH, Schuck JR, Steele L, Jonas WB: Quantitative methods in research on complementary and alternative medicine, $\mathrm{A}$ methodological manifesto, NIH Office of Alternative Medicine. Med Care 1997, 35(11):1079-94.

30. Tonelli MR, Callahan TC: Why alternative medicine cannot be evidencebased. Acad Med 2001, 76(12):1213-20.

31. Ernst E: Complementary and alternative medicine: between evidence and absurdity. Perspect Biol Med 2009, 52(2):289-303.

32. Klassen TP, Pham B, Lawson ML, Moher D: For randomized controlled trials, the quality of reports of complementary and alternative medicine was as good as reports of conventional medicine. J Clin Epidemiol 2005, 58(8):763-8

33. Verhoef MJ, Lewith G, Ritenbaugh C, Boon H, Fleishman S, Leis A: Complementary and alternative medicine whole systems research: beyond identification of inadequacies of the RCT. Complement Ther Med 2005, 13:206-12

34. Walach $\mathrm{H}$ : The Campaign Against CAM and the Notion of "EvidenceBased". J Altern Complement Med 2009, 15:1139-42.

35. Power M, Hopayian K: Exposing the evidence gap for complementary and alternative medicine to be integrated into science-based medicine. J R Soc Med 2011, 104:155-61.

36. Barry CA: The role of evidence in alternative medicine: contrasting biomedical and anthropological approaches. Soc Sci Med 2006, 62:2646-57.

37. Ventegodt S, Greydanus DE, Merrick J: Alternative medicine does not exist, biomedicine does not exist, there is only evidence-based medicine. Int J Adolesc Med Health 2011, 23(3):153-5.

38. Gillon R: Medical ethics: four principles plus attention to scope. BMJ 1994 309(6948):184-8.

39. McCarthy J: Principlism or narrative ethics: must we choose between them? Med Humanit 2003, 29(2):65-71.

40. Beauchamp T: Principles of biomedical ethics. Oxford University Press; 1979.

41. Veatch R: A theory of medical ethics. Basic Books; 1981

42. Engelhardt HT: The Foundations of Bioethics. UK: Oxford University Press; 1986.

43. Cugelman A: Therapeutic touch: an extension of professional skills. J CANNT 1998, 8(3):30-2.

44. Barnes PM, Bloom B, Nahin RL: Complementary and alternative medicine use among adults and children: United States, 2007. Natl Health Stat Report 2008, 12:1-23

45. Nahin RL, Barnes PM, Stussman BJ, Bloom B: Costs of complementary and alternative medicine (CAM) and frequency of visits to CAM practitioners: United States, 2007. Natl Health Stat Report 2009, 18:1-14.

46. Herman PM, Craig BM, Caspi O: Is complementary and alternative medicine (CAM) cost-effective? A systematic review. BMC Complement Altern Med 2005, 5:11.

47. NCCAM: Reiki: An Introduction; 2012. Available at: http://nccam.nih.gov/ health/reiki/introduction.htm. Accessed April 24, 2012.
48. Mulloney SS, Wells-Federman C: Therapeutic touch: a healing modality. J Cardiovasc Nurs 1996, 10:27-49.

49. Gallob R: Reiki: a supportive therapy in nursing practice and self-care for nurses. J N Y State Nurses Assoc 2003, 34(1):9-13.

50. Richeson NE, Spross JA, Lutz K, Peng C: Effects of Reiki on anxiety, depression, pain, and physiological factors in community-dwelling older adults. Res Gerontol Nurs 2010, 3(3):187-99.

51. Burden B, Herron MS: The increasing use of Reiki as a complementary therapy in specialist palliative care. Int J Palliat Nurs 2005, 11(5):248-253.

52. Center for Reiki Research; 2012. Available at: http://www.centerforreikiresearch.org.

53. Reiki for all creatures: Reiki for all creatures. 2012th edition; 2012. Available at: http://www.reikiforallcreatures.com.

54. Rosa L, Rosa E, Sarner L, Barrett S: A close look at therapeutic touch. JAMA 1998, 279(13):1005-10.

55. Siempos II, Spanos A, Issaris EA, Rafailidis PI, Falagas ME: Non-physicians may reach correct diagnoses by using Google: a pilot study. Swiss Med Wkly 2008, 138(49-50):741-5.

56. Tang $\mathrm{H}, \mathrm{Ng} \mathrm{JH}$ : Googling for a diagnosis-use of Google as a diagnostic aid: internet based study. BMJ 2006, 333(7579):1143-5.

57. Eysenbach $\mathrm{G}$, Kohler $\mathrm{C}$ : What is the prevalence of health-related searches on the World Wide Web? Qualitative and quantitative analysis of search engine queries on the internet. AMIA Annu Symp Proc 2003:225-9.

58. Eysenbach G, Powell J, Kuss O, Sa ER: Empirical studies assessing the quality of health information for consumers on the world wide web: a systematic review. JAMA 2002, 287(20):2691-700.

59. Thiele RH, Poiro NC, Scalzo DC, Nemergut EC: Speed, accuracy, and confidence in Google, Ovid, PubMed, and UpToDate: results of a randomised trial. Postgrad Med J 2010, 86(1018):459-65.

60. Giustini D: How Google is changing medicine. BMJ 2005, 331(7531):1487-8.

61. Steinbrook R: Searching for the right search-reaching the medical literature. N Engl J Med 2006, 354(1):4-7.

62. So PS, Jiang Y, Qin Y: Touch therapies for pain relief in adults. Cochrane Database Syst Rev 2008, 4, CD006535.

63. McCormack GL: Using non-contact therapeutic touch to manage postsurgical pain in the elderly. Occup Ther Int 2009, 16(1):44-56.

64. Maclntyre B, Hamilton J, Fricke T, Ma W, Mehle S, Michel M: The efficacy of healing touch in coronary artery bypass surgery recovery: a randomized clinical trial. Altern Ther Health Med 2008, 14(4):24-32.

65. Frank LS, Frank JL, March D, Makari-Judson G, Barham RB, Mertens WC Does therapeutic touch ease the discomfort or distress of patients undergoing stereotactic core breast biopsy? A randomized clinical trial. Pain Med 2007, 8:419-24

66. Assefi N, Bogart A, Goldberg J, Buchwald D: Reiki for the treatment of fibromyalgia: a randomized controlled trial. J Altern Complement Med 2008, 14(9):1115-22.

67. Aghabati N, Mohammadi E, Pour EZ: The effect of Therapeutic Touch on pain and fatigue of cancer patients undergoing chemotherapy. Evid Based Complement Alternat Med 2010, 7(3):375-81.

68. Nowack R, Ballé C, Birnkammer F, Koch W, Sessler R, Birck R: Complementary and alternative medications consumed by renal patients in southern Germany. J RenNutr 2009, 19(3):211-9.

69. Duncan HJ, Pittman S, Govil A, Sorn L, Bissler G, Schultz T, Faith J, Kant S, Roy-Chaudhury P: Alternative medicine use in dialysis patients: potentia for good and bad! Nephron Clin Pract 2007, 105(3):c108-13.

70. Hess S, De Geest S, Halter K, Dickenmann M, Denhaerynck K: Prevalence and correlates of selected alternative and complementary medicine in adult renal transplant patients. Clin Transplant 2009, 23(1):56-62.

71. Deng GE, Frenkel M, Cohen L, Cassileth BR, Abrams DI, Capodice JL, Courneya KS, Dryden T, Hanser S, Kumar N, Labriola D, Wardell DW, Sagar S: Society for Integrative Oncology. Evidence-based clinical practice guidelines for integrative oncology: complementary therapies and botanicals. J Soc Integr Oncol 2009, 7(3):85-120.

doi:10.1186/1471-2369-14-129

Cite this article as: Ferraresi et al:: Reiki and related therapies in the dialysis ward: an evidence-based and ethical discussion to debate if these complementary and alternative medicines are welcomed or banned. BMC Nephrology 2013 14:129. 